\title{
Law-making and accountability in responding to COVID-19: The case of New Zealand
}

\section{Dean R Knight*}

\section{What were the main mechanisms used to handle the COVID 19 challenges, both health and economic, in your country? How well did they work for the purpose?}

The high-point of the health response to Covid-19 was a state-mandated lockdown, closing businesses and requiring people to stay isolated within their household bubbles, teamed with ongoing lowerlevel restrictions. The lockdown and ongoing health response was effected through a network of different legal and extra-legal mechanisms.

First, the nationwide (and, subsequently, regional) lockdown and associated restrictions were effected through public health legislation, by the issue of a variety of health orders. For the first couple of months, the emergency power relied on was an existing and long-standing provision in section 70 of the Health Act 1956 giving medical officers of health - in this case, the Director-General of Health, acting as medical officer of health for the entire country - the power to impose restrictions to address infectious diseases. Subsequently, a bespoke (and temporary) legal framework, the Covid-19 Public Health Response Act 2020, was enacted to beef up the power to grant health orders; the primary power to issue orders was vested in the minister of health, the scope of possible orders expanded and additional decision-making principles and accountability processes were added. A series of orders were issued over time: a 7 week nationwide lockdown (including 41/2 weeks of very stringent isolation); subsequent 2 week regional lockdown in Auckland; restrictions of gathering and comingling; contact tracing measures; and ongoing border quarantine system. During the lockdown, some doubt emerged about the director-general's power to issue these nationwide isolation and closure orders. A legal challenge to his power to issue wide-ranging health orders subsequently failed (Borrowdale v DirectorGeneral [2020] NZHC 2090). However, some early expressive urgings to stay at home - made before a formal order required isolation - were found to come with heavy normative force and lacked the necessary legal underpinnings.

Secondly, a state of national emergency was declared under the Civil Defence Emergency Management Act 2002. This allowed the civil defence director to coordinate the national response, as well as allowing her to deploy various emergency direction and requisition powers. Importantly, the civil defence emergency legislation also gave the police an enforceable directive power, in cases were activity amongst the public might contribute to the pandemic emergency - a power that was used in some cases to enforce the lockdown.

Thirdly, an epidemic notice was issued under the Epidemic Preparedness Act 2006. The declaration of an epidemic empowered resort to some of the special emergency provisions in other legislation and allowed ministers to ministers activate dormant emergency provisions dotted throughout social security, immigration, penal and parole legislation. A Henry VIII power also allowed ministers to 
'modify' (viz relax) requirements or restrictions in legislation; the narrow scope - relaxation only meant this power was only used a handful of times.

Finally, messaging, nudges and urging was heavily relied on by the government. Just before the national lockdown, the government adopted an extra-legal 'alert level framework' which signalled to the public the prevailing pandemic conditions and associated suite of expected restrictions on day-today life. Levels 3 and 4 amounted to isolation and lockdown, with difference being the nature and extent of permissible personal movement and business operation. Level 2 involved lower level restrictions, regulating things like gatherings, intermingling, hospitality activity and contact tracing. Level 1 involved no mandatory restriction on day-to-day life. This alert level framework was teamed with strong messages from daily press conferences at the Beehive (the home of executive government) - the prime minister, other ministers and key officials repeatedly urging the public to do the right thing and to stay in their bubbles.

The health response was pretty effective and the elimination strategy (avoiding and containing community transmission, not full eradication) was successful, in part due to the favourable settings like late arrival of the virus in New Zealand's island nation. Early June saw the country celebrate being Covid-free (in the sense of no community transmission and no active cases) and the country returned to regular day-to-day life under alert level 1 , subject to a tight regime of managed isolation and quarantine at the border. Cases of the virus in returnees continued to be detected and managed at the border. But a case of the virus - and a growing cluster - was diagnosed in the community in midAugust. Auckland was quickly put in level 3 lockdown - for 17 days - and swift efforts were made to contain the cluster and prevent further transmission.

Economic and welfare support was implemented by a reconfigured budget and specific legislative measures. In March, going into the first lockdown, the government announced a $\$ 12$ billion economic response package, passed as an imprest supply bill and associated taxation bill. This provided an initial wage subsidy, other business and welfare initiatives and additional health funding. In May, in the usual budget cycle, a rewritten 'rainy-day' budget was announced. Its centrepiece was a further $\$ 50$ billion for a response and recovery fund, committed to economic, stimulus and welfare initiatives, along with additional administration costs. Around $\$ 20$ billion of that fund was set aside - unallocated and as yet unappropriated - for further possible initiatives, allowing the government to continue economic, stimulus and welfare initiatives as necessary during any second wave of the pandemic or economic slump. At the end of August, around \$14 billion remains unallocated.

Like the health response, the economic response was relatively successful in mitigating forecast dire economic downturn and associated effects, in part because the government aligned the two. In other words, the government focused on a swift health response - 'going hard and going early' - so as to hopefully minimize economic disruption. While, of course, economic activity and community wellbeing suffered through the pandemic, the limited lockdown and support initiatives produced some promising results. For example, economic activity in June was only down $1 \%$ on the prior year.

\section{To what extent were responses to the pandemic influenced by the parliamentary/ presidential/semi-presidential structure of your country?}

New Zealand's Westminster-style parliamentary system, including multi-party government, has shaped the nature of the response to some degree - with involvement of both branches of government. The response to the pandemic has been led by executive government, with the prime minister, ministers and officials adopting a whole-of-government approach. However, the 
government has also been held to account by the opposition through parliamentary and other processes.

While most of the emergency health measures are vested in ministers or officials, the triggering of these powers must be reported to Parliament (eg, issue of an epidemic notice and declaration of state of national emergency). Similarly, Parliament has responsibility to supervise - and disallow - most executive measures (eg, most health orders under the Health Act 1956 and all health orders under the Covid-19 Public Health Response Act 2020 are disallowable instruments). Some of Parliament's processes and business were re-organised to ensure that opposition and other MPs could exact accountability and contribute to the response (see below). In addition, legislative action was also required to effect some of the economic, stimulus and welfare support.

Cabinet decision-making about the pandemic and response also reflected existing governance arrangements adopted by political parties, modified as necessary to reflect the gravity of the emergency and need for responsive. The government itself is a multi-party one: the Labour party is the lead party in government, in coalition with the NZ First party and with confidence-and-supply support from the Green party. Labour has the most Cabinet ministers and NZ First has a handful; the Green party has a few ministers outside Cabinet. Major decisions about the response were made by Cabinet itself. A small ministerial group, including one Green minister, was also established to coordinate the response and to address urgent matters; all three parties are represented on this group. While the Green party does not have a seat at the Cabinet table per se (except as invited on an ad hoc basis), it was fully briefed on key proposals beforehand and provided its support. The usual unity-distinctive tension associated with multi-party government continued throughout the pandemic. In the early days and throughout lockdown, the importance of the singular view from government meant strong solidarity was shown; in latter days and closer to the election, coalition and support parties expressed some different party views, as governing arrangements allow.

The relationship between Cabinet and the public service was also carefully navigated. During the first lockdown, emergency powers were formally exercisable by the director-general of health, not ministers. However, the director-general and Cabinet engaged in a delicate tango to ensure the former's independence was preserved but the latter's democratic legitimacy also wrapped around key decisions. The extra-legal alert level system provided Cabinet a transparent means to express its expectations, without unduly fettering the director-general's consequential public health powers. And the director-general and Cabinet were almost always on the same page throughout lockdown. But things could well have been different if the director-general and Cabinet favoured different approaches.

If elections were due during the emergency period, were they held or postponed? If they were held, what concessions were made to the emergency conditions? If they were postponed, with what consequences?

Election day was scheduled for 19 September 2020 but was recently delayed to 17 October 2020. The delay was triggered by the recently diagnosed community cluster in Auckland, on the eve of Parliament being dissolved for the election and as the hustings were heating up.

The decision to delay was made by the prime minister, in accordance with her power to advise the governor-general on dissolution of Parliament and the election day. A predicted constitutional crisis based on the possibility that the prime minister may not delay the election even though most of Parliament, including one of her coalition parties, wanted the election delayed - did not realise. 
The prime minister had announced the September election date well in advance, in late January, in accordance with a developing convention of early notice. In mid-August, the formal arrangements for the election were to be implemented. The night before the Governor-General's proclamation dissolving Parliament was due to be publicly read, the Auckland outbreak was announced and the city was locked down. The House of Representatives had wound up the week prior: adjourned in anticipation of dissolution of Parliament. MPs had left the capital for the hustings. Given the uncertain impact on the election, the prime minister advised the governor-general to temporarily delay the dissolution of Parliament and issue of the writ by a few days to give time to breathe.

Dissolution would have triggered a chain of election milestones and it would have been tricky to change tack: (a) the chief electoral officer has emergency adjourning powers under the Electoral Act 1993 for unforeseen or unavoidable disruptions such as pandemics but only week-by-week (albeit unlimited); (b) if extension of the term of Parliament was needed (beyond constitutional expiration in late October), a $75 \%$ majority vote would have been needed because the parliamentary term is entrenched. However, as Parliament had not formally dissolved, the prime minister still had authority to advise the governor-general to delay the dissolution of Parliament and scheduled election date. Opposition parties favoured delay. So too did NZ First, Labour's coalition partner. Thus, there was some speculation about whether the opposition and NZ First could conspire to seize control of the decision about the election date, if the prime minister was unwilling to delay it - possibilities which depended on confidence and the caretaker convention (ie, if confidence was lost, requesting dissolution is then subject to the caretaker convention requirement of majority support in the House).

The Prime Minister avoided these potential shenanigans by extending the date for the election by 4 weeks. In doing so, the prime minister said the decision to delay was not an ordinary decision so she had reached out and taken soundings from parliamentary parties and others, as well as considering advice from the independent electoral commission on the practicalities of delay.

\section{Were there departures from usual practice in the ways in which the legislative functions of law-making, representation and holding the government to account were managed during this time?}

Parliament was affected by the lockdown and physical distancing requirement for a short period. Thus it adopted some innovative and different practices, through sessional orders, so it could continue to effectively conduct its business.

First, the House of Representatives adjourned for just over a month during the level 4 lockdown (from 25 March 2020 until 28 April 2020). However, other processes continued: for example, some select committees continued to meet electronically (mainly considering some pressing non-pandemic legislation) and written questions continued (albeit with relaxed timeframes). The House resumed at alert level 3, sitting for three working weeks during that period of lockdown. During this time, rules were adjusted to accommodate physical distancing and other health requirements. For example, the proxy voting rule was relaxed in order to reduce the number of members of Parliament needed in the House when sitting and limited numbers of MPs attended in person (less than a quarter). Electronic administration of some administrative processes was also allowed. Over this period, the business of the House was mainly focused on the budget and pandemic-related legislation and scrutiny of the executive's emergency response. With the move to alert level 2 in mid-May, usual operation of Parliament resumed. 
Secondly, an Epidemic Response committee was established to scrutinise the government's actions. In many respects, this committee became New Zealand's 'parliament-in-miniature' during the lockdown. Chaired by the leader of the opposition and with an opposition majority, it was given plenary powers to inquire into the government's ongoing response to Covid-19. During the lockdown, it met three mornings a week - questioning key ministers and officials, as well as hearing from experts and those adversely affected. The committee was quite effective, especially in its first few weeks of operation during the lockdown. It pressed on many of the operational challenges and soft points of the lockdown, playing an important agenda-setting role in political discourse. But its proceedings eventually became more partisan and a little less constructive, especially once the height of the emergency passed. It ceased operating once usual parliamentary procedures fully resumed in lateMay.

Thirdly, as mentioned above, lockdown and other restrictions were primarily imposed through health orders - made under the Health Act 1956 or Covid-19 Public Health Response Act 2020. As a form of secondary legislation, these orders were subject to parliamentary scrutiny and potentially disallowance (and judicial scrutiny and invalidation too). The regulations review committee launched an inquiry in the orders issued, raising a number of matters of concern with the director-general about some of the early orders. As disallowable instruments, health orders may be disallowed by the House through usual secondary legislation processes. Parliamentary oversight was also fortified in the Covid19 Public Health Response Act 2020. Health orders now need to be approved by the House within a set period once made or else they are automatically revoked. The empowering legislation itself is also subject to a sunset provision: it is automatically repealed unless the House resolves to renew it every 90 days.

Fourthly, Parliament continued to legislate to implement measures that could not be effected through existing executive powers and, once alert levels lowered and day-to-day business returned, to pass other non-pandemic legislation that needed to be enacted before the election. Nearly 60 pieces of legislation were passed since the pandemic was declared: (a) a handful of health measures; (b) half a dozen budget-related bills; $(c)$ ten bills providing economic and welfare support or implementing pandemic-relating governance and administrative changes; and (d) nearly 40 pieces of non-pandemic legislation.

Fifthly, much of the legislation was passed under expedited processes, such as urgency, extended sittings or agreed truncation of debates. Almost all non-pandemic legislation was considered by select committees, in accordance with usual processes for public submission and scrutiny (albeit usual arrangements for public submissions was a little truncated in some cases). However, only a few of pieces of pandemic legislation were scrutinised by select committee. The expedition of legislation was not without some controversy. In one case, the wrong version of a bill implementing economic support was tabled in error and passed through all three readings before anyone noticed. The lack of public participation in the law-making process also caused concern, especially in relation to the enactment of the key piece of legislation in the public health framework. The Covid-19 Public Health Response Act 2020 was passed in two days on the eve of the alert level lowering to level 2 - without any opportunity for public submission and select committee scrutiny. However, in response to the criticism and on the government's own motion, the legislation was referred to a select committee for immediate post-enactment review and public input. The initiative was a welcome innovation to partly ameliorate the lack of pre-enactment public submission. However, the select committee's report was perhaps disappointingly general in its examination, when many concerns related to detailed aspects 
of the legislation's wording. Also, some other pandemic legislation was only subject to very short select committee scrutiny and selected public comment.

Finally, while the quantum of government spending grew during the pandemic, usual budget processes and parliamentary examination continued. In addition, the Controller and Auditor-General brought heightened scrutiny to government spending and financial processes during the pandemic, as well as providing additional guidance to departments and agencies about financial integrity during the emergency settings.

\section{Overall, what has been the effect of the pandemic on the balance between the authority of the legislature and the executive? Do you expect it to have long-term consequences?}

The heavy-lifting during the pandemic has undoubtedly been done by the executive. However, the precious role of the legislature - both as supreme law-maker and as primary forum for executive accountability - has also largely been maintained, even if its profile has been slightly eclipsed by the frequency and loudness of executive action. In other words, the pandemic has probably not fundamentally changed the balance of authority in New Zealand - where executive-parliamentary interaction and partnership has always been central and critical. The lack of significant change is probably due to the relatively straight-forward governance arrangements (small democracy, with a unitary, unicameral, parliamentary system and multi-party but collaborative Cabinet government) and the short period of heightened alert levels and disruption.

What positive or negative lessons can be taken from this experience in your country for the role and procedures of the legislature during an emergency of this kind?

The Covid-19 pandemic has inevitably highlighted the importance of future proofing institutions for unexpected disruption. However, the unknown nature of some disasters and emergencies also means institutions ultimately need to be responsive and nimble - capable of implementing bespoke arrangements and processes suitable for the circumstances that arise. The success of the latter depends a lot on the institutional and political commitment to values of democracy, legitimacy and accountability. New Zealand's executive and legislature were generally able to stay true to these values while pragmatically innovating civic processes, simultaneously delivering a strong response to the pandemic.

Biography: Dean Knight is an Associate Professor, Faculty of Law and New Zealand Centre for Public Law; Victoria University of Wellington. He specialises in public and government law. Areas of particular emphasis in his work include judicial review of administrative action, local government and democracy, and constitutional reform. Dean graduated from Victoria University of Wellington with LLB(Hons) and BCA degrees, rejoining the faculty of law as an academic in 2005 after a number of years in practice in with an Australasian law firm (specialising in litigation, public law and local government). He has completed an LLM (by thesis) at the University of British Columbia, Canada and a PhD at London School of Economics and Political Science in the United Kingdom. Dean is a member of the NZ Centre for Public Law, co-chair of the Australasian chapter of the International Society of Public Law (ICON-S AU-NZ) and an executive committee member of the Law and Society Association of Australia and New Zealand (LSAANZ). He also serves on the editorial committee of the NZ Journal of Public and International Law. Dean has recently been a Visiting Fellow at the London School of Economics and Political Science and an International Visiting Fellow at the Bingham Centre for the Rule of Law at the British Institute of International Comparative Law. 